\title{
Piotr Czerkawski
}

Uniwersytet Wrocławski

\section{EUROPA BIJE SIĘ W PIERSI - RECENZJA KSIAZZZKI POSTKOLONIALNA EUROPA. ETNOOBRAZY WSPÓECZESNEGO KINA KRZYSZTOFA LOSKI}

DOI: 10.19195/0860-116X.38.13

Kino od początku swego istnienia reaguje na otaczającą rzeczywistość i skłania do pogłębionej refleksji nad charakteryzującymi ją procesami. Nic zatem dziwnego, że dziś - w dobie wyczuwalnych w Europie Zachodniej napięć między rdzenną ludnością a przybyszami z zewnątrz, a także tak zwanego kryzysu migracyjnego - tematy te coraz częściej znajdują swoje odzwierciedlenie w filmach. Wzrost liczby produkcji zwracających uwagę zarówno na pozytywne, jak i problematyczne aspekty funkcjonowania wielokulturowych społeczeństw europejskich nie uszedł również uwagi badaczy kina. Za najbardziej przydatne narzędzie analityczne większość z nich słusznie uznała dyskurs postkolonialny. Książka Postkolonialna Europa. Etnoobrazy współczesnego kina Krzysztofa Loski stanowi niezwykle udaną próbę wykorzystania go także na gruncie polskiego filmoznawstwa ${ }^{1}$. Lista zalet publikacji autorstwa profesora Uniwersytetu Jagiellońskiego nie kończy się bynajmniej na interesującym doborze tematu. Postkolonialna Europa robi wrażenie także

1 Próby te podejmowano, oczywiście, także przed publikacją Postkolonialnej Europy. Teksty filmoznawcze utrzymane w obrębie dyskursu postkolonialnego są regularnie drukowane choćby w poznańskim piśmie „Porównania”. Bodaj żaden autor przed Loską nie poważył się jednak na stworzenie publikacji równie kompleksowej. 
ze względu na rozmach przeprowadzonych badań, erudycję autora, precyzję stylu i błyskotliwość ujawnianą w szczegółowych interpretacjach omawianych filmów.

Atutem książki Loski pozostaje z pewnością także przejrzysta kompozycja. We wstępie zatytułowanym Postkolonialny zwrot $w$ badaniach nad filmem krakowski filmoznawca szczegółowo opisuje wybraną metodologię. Aby zapobiec zaistnieniu terminologicznych niejasności, stwierdza:

Pisząc o zwrocie postkolonialnym w badaniach nad filmem, trzeba zacząć od pytania, czym jest postkolonializm, zważywszy na wieloznaczność tego terminu oraz mnogość wzajemnie wykluczających się stanowisk. Podobnie jak w pokrewnym pojęciu — postmodernizm przedrostek ,post” nie oznacza bynajmniej następstwa czasowego i końca pewnej epoki (w tym wypadku kresu kolonializmu), lecz konieczność przemyślenia na nowo podstawowych kwestii i zagadnień mających swe źródła w niezbyt odległej historii. Chodzi o zwrócenie uwagi na nieustanne oddziaływanie przeszłości na teraźniejszość, wpływ ekonomicznego i kulturowego dziedzictwa imperiów, kwestię rasowej, etnicznej i płciowej tożsamości².

Właściwy tekst publikacji podlega podziałowi na dwie części. Pierwsza skupia się na refleksji na temat postkolonialnych aspektów kina francuskiego. Poświęcenie tak dużej uwagi jednej tylko kinematografii wydaje się w pełni uzasadnione ze względu na bogatą przeszłość kolonialną Francji, znaczącą obecność imigrantów w tamtejszym społeczeństwie, a wreszcie także na dużą liczbę filmów odnoszących się do tych zagadnień. Druga część książki skupia się na śledzeniu postkolonialnych tropów w innych kinematografiach europejskich, ze szczególnym uwzględnieniem brytyjskiej.

Jedyną wątpliwość związaną z kompozycją Postkolonialnej Europy należałoby zgłosić pod adresem zakończenia. Służący za epilog szkic Hybrydowość i transkulturowy pejzaż muzyczny, analizujący z perspektywy postkolonialnej ścieżki dźwiękowe wybranych filmów ze Starego Kontynentu, jest sam w sobie zajmujący. Trudno jednak zorientować się, dlaczego Loska zdecydował się zamieścić go na samym końcu swych rozważań. Pewnego rodzaju wyjaśnienie przynoszą dopiero ostatnie słowa tekstu, w których autor stwierdza, że

Muzyka zawiera w sobie transkulturowy potencjał, który zachęca do przezwyciężenia ograniczeń wynikających z definiowania kultur jako zamkniętych całości, umożliwia tworzenie powiązań między pozornie odległymi obszarami i wskazuje na korzyści płynące z przenikania się wpływów ${ }^{3}$.

Choć z tak wyrażoną tezą nie sposób się nie zgodzić, trudno jednocześnie oprzeć się wrażeniu, że jej charakter pozostaje zbyt wąski, by posłużyć za puentę całej, wielowątkowej publikacji.

2 K. Loska, Postkolonialna Europa. Etnoobrazy współczesnego kina, Kraków 2016, s. 8.
3 Ibidem, s. 331. 


\section{FRANCUSKIE POTYCZKI Z PRZESZŁOŚCI}

Najobszerniejszy rozdział Postkolonialnej Europy, poświęcony kinematografii francuskiej, okazuje się jednocześnie najbardziej wartościową częścią książki. Już w pierwszych fragmentach swoich rozważań Loska udowadnia, że potrafi doskonale opisać sposób, w jaki kino wchodzi w relacje z rzeczywistością pozafilmową i staje się nośnikiem ideologii. Szczególnie interesująco wypadają pod tym względem refleksje autora na temat ekranowych obrazów takich wydarzeń, jak procesy dekolonizacyjne w krajach afrykańskich czy będąca ich następstwem, trwająca w latach 1954-1962, wojna w Algierii.

Krakowski badacz wykazuje też dużą swadę w odsłanianiu imperialnego oblicza kinematografii francuskiej opowiadającej o swoich byłych koloniach w sposób pełen arogancji i kulturowej wyższości. Próbkę umiejętności autora, który przekonująco obnaża nieczyste intencje francuskich reżyserów, zawiera choćby fragment poświęcony głośnym Indochinom. W ramach szczegółowej analizy filmu Régisa Wargniera Loska zauważa między innymi, że

Adopcja małej księżniczki wietnamskiej przez główną bohaterkę staje się kluczową metaforą wyjaśniającą charakter kolonialnych zależności. Podbite kraje są jak małe dzieci, wymagają opieki i dyscypliny, trzeba je nauczyć właściwego zachowania, muszą przyswoić normy kulturowe, by upodobnić się do swoich rodziców/panów ${ }^{4}$.

Choć Postkolonialna Europa pełna jest tego rodzaju demaskatorskich odczytań, autor bynajmniej nie poprzestaje wyłącznie na nich. Zamiast tego chętnie przywołuje tytuły, które potrafiły wykroczyć poza powielanie krzywdzących stereotypów o życiu w byłych francuskich koloniach. Szczególnie cenny wydaje się pod tym względem poczyniony przez Loskę obszerny komentarz na temat - wciąż jeszcze niecieszącej się w Polsce należytą rozpoznawalnością ${ }^{5}$ — twórczości Claire Denis. Reżyserka Pięknej pracy jest dla autora tak ważną figurą, gdyż choć spędziła dzieciństwo w skolonizowanej przez Francuzów Afryce, w swoich filmach nie opowiada o czasach młodości w sposób bezkrytyczny i dba o to, by zawrzeć na ekranie również perspektywę Innego. Tego rodzaju odkryć jest w książce krakowskiego profesora znacznie więcej. Lektura Postkolonialnej Europy z pewnością zachęci czytelnika także do sięgnięcia po takie - słabo znane dotychczas w Polsce, a chwalone przez Loskę - tytuły, jak Dwadzieścia nocy i jeden deszczowy dzień Lama Le czy Lato w La Goulette Ferida Boughedira.

Równie dużą zaletę książki Loski stanowi zwrócenie uwagi na możliwość zaznaczenia nieoczywistej postkolonialnej perspektywy w interpretacji dobrze znanych już w Polsce tytułów. Szczególnie wartościowe okazują się pod tym względem

4 Ibidem, s. 69.

5 Być może na zmianę tej sytuacji wpłynie przebieg festiwalu Nowe Horyzonty 2016 we Wrocławiu, w trakcie którego dwa filmy Denis zostały zaprezentowane w elitarnej sekcji „Mistrzowie Kina Europejskiego", a sama autorka przyjechała do Polski i przedstawiła je publiczności. 
rozważania na temat Ukrytego Michaela Hanekego. Autor ciekawie interpretuje wybór głównego bohatera, który wyrzekł się kontaktu ze swym przybranym bratem pochodzenia arabskiego, jako „Ilustrację pewnej tendencji obecnej w społeczeństwie francuskim, związanej z historyczną amnezją, odrzuceniem odpowiedzialności za okres kolonializmu i niechęcią do naprawienia krzywd"6. Ciekawego komentarza Loski doczekał się także - eksponowany przez Hanekego - wątek braku wiary w terapeutyczną moc obrazów. Według autora Postkolonialnej Europy pesymizm Ukrytego stanowi kolejną płaszczyznę odróżniającą go od typowych, nostalgicznych filmów postkolonialnych powstających zwykle, by nieść widzowi pocieszenie.

\section{PODWAŻANIE STEREOTYPÓW}

Krakowski badacz przytomnie zauważa, że termin „kino postkolonialne” nie musi odnosić się wyłącznie do filmów traktujących o przeszłości. W równym stopniu jest on adekwatny w stosunku do dzieł opisujących sytuację zamieszkujących Francję imigrantów bądź ich potomków. Dlatego właśnie ważny element Postkolonialnej Europy stanowi refleksja nad — rozwijającym się w Paryżu i innych francuskich miastach od połowy lat dziewięćdziesiątych — ,kinem blokowisk” (cinema de banlieue).

We fragmentach poświęconych filmom na temat sytuacji młodych Francuzów $z$ rodzin imigranckich Loska łączy perspektywę filmoznawcy z celnymi intuicjami socjologicznymi. Tak dzieje się na przykład, gdy stwierdza, że „Młodzież z etnicznych blokowisk zauważa sprzeczność między głoszonym przez władzę abstrakcyjnym uniwersalizmem negującym kwestię różnicy rasowej a codziennym życiem w dyskryminacji" ". Za przestrzeń ukrytej segregacji autor Postkolonialnej Europy uznaje między innymi francuską szkołę, której realia są ostatnio przedstawiane w coraz większej liczbie filmów.

Zupełnie jak w części poświęconej rozrachunkom z przeszłością Loska, śledząc ekranowe obrazy francuskiej edukacji, piętnuje tytuły oparte na pełnym uprzedzeń stosunku do Innego, by przeciwstawić im dzieła głębsze i znacznie mniej tendencyjne. Różnicę tę w najbardziej sugestywny sposób eksponuje w ramach analizy porównawczej dwóch filmów - Pokolenie nienawiści Jean-Paula Lilienfelda i nagrodzona Złotą Palmą w Cannes - Klasa Laurenta Canteta. Pierwszy film jest przez autora dyskredytowany ze względu na przedstawienie wyraźnie negatywnego obrazu środowiska imigrantów i posługiwanie się przez reżysera stereotypami. Drugi natomiast jest chwalony za niejednoznaczność przekazu, którą Loska opisuje słowami:

\footnotetext{
6 K. Loska, op. cit., s. 97.

7 Ibidem, s. 138.
} 
Niektóre sceny rozgrywające się w sali lekcyjnej sugerują, że szkoła może stać się miejscem negocjowania tożsamości kulturowej, wyrażania własnych poglądów, a nie tylko przyswajania kultury dominującej. Inne jednak ujawniają napięcia między uczniami pochodzącymi z byłych kolonii, pokazują też, że próby porozumienia podejmowane przez młodego nauczyciela nie zawsze są skuteczne, że istnieje przepaść pomiędzy wymogami narzuconymi przez pakt edukacyjny, mający stworzyć lepsze warunki do integracji, a jego skutkami ubocznymi w postaci procesu wykorzenienia ${ }^{8}$.

Kolejnym, oprócz Canteta, reżyserem, którego dorobek doczekał się w Postkolonialnej Europie życzliwej interpretacji, okazał się Abdellatif Kechiche. Autor chwali urodzonego w Tunezji filmowca za to, że - podobnie jak twórca Klasy — ,postanowił podważyć dominujący, czyli negatywny stereotyp młodzieży pochodzącej z mniejszości etnicznych i pesymistyczny wizerunek blokowisk jako siedliska przemocy"9. W błyskotliwym szkicu na temat filmu Unik Loska chwali Kechiche'a za podważenie - charakterystycznej dla francuskiego kina — opozycji między centrum i peryferiami, i pokazaniem na ekranie sytuacji, gdy kojarzona z centrum kultura wysoka wkracza na imigranckie obrzeża. Urodzony w Tunezji twórca, który jest laureatem Złotej Palmy w Cannes, urasta do rangi jednego z najważniejszych bohaterów książki i służy w niej za wzorzec imigranta mogącego odnieść sukces we francuskim przemyśle filmowym.

\section{PODRÓŻ PO NIKNĄCYM IMPERIUM}

Wysoki poziom rozdziału o filmach francuskich udało się autorowi utrzymać także w części poświęconej kinematografii brytyjskiej. Loska ponownie wzbogacił refleksje na temat X muzy o konteksty polityczne. Wzrost liczby filmów opowiadających o bogatej kolonialnej przeszłości Wielkiej Brytanii został na przykład wyjaśniony przez krakowskiego profesora jako konsekwencja polityki Margaret Thatcher dążącej do redefinicji angielskiej tożsamości i ponownego oparcia jej na konserwatywnych przekonaniach oraz imperialnych tęsknotach.

Z Postkolonialnej Europy dowiemy się, że filmy powstałe w tym klimacie politycznym zostały określone jako kino dziedzictwa, które „służyło wzmacnianiu poczucia przynależności oraz symbolizowaniu jedności wewnętrznej rzeczywistych lub sztucznych wspólnot, a także upowszechnianiu i wpajaniu systemów wartości" " Należące do nurtu tytuły, takie jak Gandhi Richarda Attenborough czy Podróż do Indii Davida Leana, były przed laty ostro krytykowane przez obficie cytowanego w Postkolonialnej Europie Salmana Rushdiego. Autor Szatańskich wersetów pisał o „filmach dziedzictwa”, że zawarte w nich wizje Orientu to takie

\footnotetext{
8 Ibidem, s. 139.

9 Ibidem, s. 142.

10 Ibidem, s. 170.
} 
same fałszywe portrety jak te, które ,przed laty miały stanowić moralne, kulturowe i artystyczne uzasadnienie imperializmu i leżącej u jego podstaw ideologii głoszącej wyższość rasy białej nad azjatycką"11.

Loska potwierdza intuicje Rushdiego, lecz jednocześnie dostrzega, że z biegiem czasu brytyjscy filmowcy zmienili swój stosunek do kolonialnego dziedzictwa. Pokaźną część „brytyjskiego” rozdziału Postkolonialnej Europy stanowi refleksja nad osadzonymi w czasach współczesnych filmami, które pokazują korzyści z funkcjonowania wielokulturowego społeczeństwa i zwracają uwagę na możliwość pozytywnego zakończenia procesu asymilacji imigrantów. Brytyjskie kino, coraz bardziej otwarcie celebrujące kulturową różnorodność, wydaje się zresztą znacznie bardziej optymistyczne niż traktujące ją wciąż podejrzliwie filmy francuskie. Otwarte pozostaje pytanie, czy tendencja ta utrzyma się wraz ze wzrostem zachowań nacjonalistycznych sprowokowanych przez tak zwany Brexit.

Póki co, jak zauważa autor Postkolonialnej Europy, wątki imigranckie są w kinie brytyjskim chętnie podejmowane zarówno przez reżyserów komercyjnych filmów w stylu Podkręć piłkę jak Beckham, jak i twórców kina artystycznego. Spośród tych ostatnich szczególnie ciekawie wypada w książce Loski Stephen Frears. Zrealizowane przez tego reżysera jeszcze w latach osiemdziesiątych filmy, takie jak Moja piękna pralnia czy Sammy i Rosie puszczaja się, zostają przedstawione jako pierwsze tytuły, które w przedstawianiu obcych zerwały z ograniczającą optyką „,kina dziedzictwa”, a później mogły być traktowane jako wzorzec dla kolejnych twórców podejmujących podobną tematykę.

\section{DOGONIĆ RZECZYWISTOŚĆ}

Jedyny poważniejszy zarzut wobec Postkolonialnej Europy musi dotyczyć faktu, że choć autor podjął się trudu opisania bardzo wielu tytułów, nie wspominał o kilku filmach, których nieobecność była w trakcie lektury bardzo odczuwalna. Trudno na przykład zrozumieć, dlaczego Loska, poświęcając tak wiele miejsca obrazom wojny w Algierii, pominął Dzikie trzciny André Techiné. W opowiadającym o splocie ideologii i pożądania filmie kluczową rolę odgrywa przecież relacja młodego Algierczyka i gniewnego repatrianta. Choć istotne wątki postkolonialne znajdują się też w takich filmach francuskiego reżysera, jak Niewinni czy Utracona miłość, jego nazwisko nie zostało wymienione w książce Loski ani razu.

Podobny niedosyt wzbudza również brak wzmianki o Proroku Jacques'a Audiarda, w którym zaludnione przez outsiderów złożonych z wielu grup etnicznych więzienie stanowiło zgrabną metaforę francuskiego społeczeństwa. Szkoda również, że Loska zignorował komercyjny fenomen Nietykalnych Olivera Nakache

\footnotetext{
11 S. Rushdie, Ojczyzny wyobrażone, przeł. E i T. Hornowscy, Poznań 2013, s. 93.
} 
i Erica Toledano, a wspominając o Czułym pocałunku Kena Loacha — nie zająknął się o wyreżyserowanym przez tego samego twórcę Polaku potrzebnym od zaraz.

Wyliczankę tę można by kontynuować jeszcze długo, ale lepiej przyznać chyba, że temat poruszony przez autora jest po prostu zbyt szeroki, by dało się wyczerpać go w obrębie jednej książki. Myślenie to wydaje się uprawnione, tym bardziej że liczba filmów opowiadających o imigracji i innych następstwach kolonializmu ostatnimi czasy rośnie lawinowo. Bez - powstałych już zapewne po oddaniu książki do druku - filmów takich jak Fuocoammare Gianfranco Rosiego, Imigranci wspomnianego Audiarda trudno będzie zresztą wyobrazić sobie jakąkolwiek przyszłą książkę o postkolonializmie w kinie. Niezależnie jednak od charakteru tych publikacji znakomita Postkolonialna Europa z całą pewnością stanowić będzie dla nich ważny punkt odniesienia i pożyteczne źródło inspiracji.

\title{
EUROPE REPENTANT. REVIEW OF POSTCOLONIAL EUROPE: ETHNO-REPRESENTATIONS IN CONTEMPORARY CINEMA BY KRZYSZTOF LOSKA
}

\begin{abstract}
Summary
The subject of the present paper is a book „Postkolonialna Europa. Etnoobrazy współczesnego kina" by professor Krzysztof Loska from the Jagiellonian University, focused on an attempt to analyse the cinema of the Old Continent from post-colonial point of view. The review underlines a valuable contribution to Polish film studies that the book makes and emphasizes the scale of research undertaken, as well as the manner accuracy and the ability to perform a witty interpretation of each and every movie. In accordance to the reasoning included in the review, all these features can be noticed in particular in the chapters dedicated to the French cinema. In the present paper the author also pays attention, though, to omission of few movies that are strongly tied to the subject of Loska's considerations and some irrelevance of the chapter named „Hybrydowość...” in relation to the rest of the book. However, those little concerns do not affect a very high rating of the quality of the reviewed book.
\end{abstract}

Translated by Kordian Bobowski 